\title{
Możliwość pełnienia funkcji przez prezydenta miasta (wójta, burmistrza) ukaranego karą grzywny
}

Can a mayor penalized with a fine remain in office?

\author{
dr hab. prof. Ut Krzysztof Stefański
}

Uniwersytet Łódzki, Wydział Prawa i Administracji,

Katedra Prawa Pracy

ORCID: 0000-0001-6313-7387

kstefanski@wpia.uni.lodz.pl

\begin{abstract}
Streszczenie Dla sprawnego i uczciwego realizowania zadań publicznych niezwykle istotny jest właściwy dobór pracowników, zwłaszcza tych pełniących najważniejsze funkcje. Dobór ten musi uwzględniać zarówno przygotowanie merytoryczne, jak i postawę etyczną kandydatów. Jednym z jej wyznaczników jest niekaralność. Niestety, przepisy polskiego prawa wykazują w tym względzie istotną niespójność, w szczególności w odniesieniu do funkcji prezydenta miasta (wójta, burmistrza).
\end{abstract}

Słowa kluczowe: prezydent miasta, niekaralność, kryteria selekcyjne, wybór.

Summary Officials, especially high-level officials, should meet the highest professional and ethical standards. The legislator should guarantee this by introducing appropriate statutory criteria, such as criminal record. Unfortunately, the provisions of Polish law are inconsistent, especially with regard to the function of city mayor. The article indicates these defects of legal regulations.

Keywords: mayor, criminal record, election.

JEL: K16, K31

Str. 29-33

\section{Bibliografia}

Bessaraba, R. (2000). Stosunek pracy na podstawie wyboru. Ga zeta Prawna, (37).

Dubowik, A., Pisarczyk, Ł. (2011). Prawo urzędnicze. Warszawa.

Giedrewicz-Niewińska, A. (2017). Nawiązanie stosunku pracy z wyboru. W: Z. Góral (red.), System prawa pracy. Tom IV. Indywidualne prawo pracy. Pozaumowne stosunki pracy. Warszawa.

Góral, Z. (200). Swoistości stosunków pracy pracowników samorządowych. W: Z. Kubot (red.), Szczególne formy zatrudnienia. Wrocław.

Kisielewicz, A. (2014). Komentarz do art. 11. W: K. W. Czaplicki, B. Dauter, S. J. Jaworski, A. Kisielewicz, F. Rymarz, Kodeks wyborczy. Komentarz. Warszawa.

Piątkowski, J. (1994). Wrowadzenie do prawa stosunku pracy. Toruń.

Płażek, S. (2016). za: M. Cyrankiewicz, Praca w samorządzie: wójt może być kryminalistą. Rzeczpospolita z 12.07.2016. RóżańskaDorosz, I. (2003). Stosunek pracy: powołanie, mianowanie, wybór, spótdzielcza umowa o pracę. Wrocław.

Rzetecka-Gil, A. (2018). Konsekwencje ukarania karą grzywny za przestępstwo ścigane z oskarżenia publicznego z perspektywy możliwości pełnienia funkcji wójta, burmistrza, prezydenta miasta. Monitor Prawniczy, (18).

Stelina, J. (2015). Podstawy zatrudnienia pracowników samorządowych. Gdańskie Studia Prawnicze, 2.

Wilk, L. (2018). Komentarz do art. 106. W: M. Filar, Kodeks karny. Komentarz. Warszawa 